\title{
INTEGRACJA GOSPODARCZA DANII, FINLANDII I SZWECJI Z UNIĄ EUROPEJSKA
}

\section{Wprowadzenie}

Współpraca Skandynawów w dziedzinie nauki, technologii, kultury i ekologii jest warunkiem przyspieszonego i zrównoważonego rozwoju społeczno-gospodarczego tego regionu.

Od lat 70. XX w. w krajach skandynawskich ${ }^{1}$ toczą się dyskusje na temat członkostwa w zachodnioeuropejskiej wspólnocie gospodarczej. Podstawą rozmów są możliwości współpracy regionu skandynawskiego z Unią Europejską i Unią Gospodarczą i Walutową. Interesujący pod względem naukowym jest udział Danii, Finlandii i Szwecji w strukturach unijnych oraz stopień i sposób zintegrowania tychże gospodarek, w kontekście globalnego kryzysu finansowego².

Obszar badawczy w niniejszym opracowaniu obejmuje integrację krajów skandynawskich z Unią Europejską oraz Unią Gospodarczą i Walutową.

W pracy przyjęto tezę: zróżnicowana reakcja gospodarek krajów skandynawskich na globalny kryzys wynikała z przyjęcia odmiennych rozwiązań instytucjonalnych w zakresie polityki gospodarczej.

Celem opracowania jest krytyczna ocena przebiegu integracji Danii, Finlandii i Szwecji z Unią Europejską oraz ocena skutków przystąpienia Finlandii do Unii Gospodarczej i Walutowej, przyjęcia przez Danię klauzuli opt-out oraz objęcia Szwecji derogacją.

1 W zgodzie z literaturą przedmiotu oraz dla uproszczenia w pracy przyjęto definiowanie krajów skandynawskich jako wybrane kraje nordyckie należące do Unii Europejskiej, to jest Dania, Finlandia i Szwecja. B. Piotrowski, Integracja Skandynawii. Od Rady Nordyckiej do Wspólnoty Europejskiej, UAM Wydawnictwo Naukowe, Poznań 2012.

2 Dla celów opracowania przyjęto definicję globalnego kryzysu finansowego jako kryzysu zapoczątkowanego w 2007 r. Pojęcie to będzie stosowane zamiennie z określeniami „kryzys globalny” i „kryzys finansowy". S. Claessens, M.A. Kose, L. Laeven, F. Valencia, Financial Crises Causes, Consequences, and Policy Responses, International Monetary Fund, Washington 2014. 
Metody badawcze wykorzystane w pracy to: krytyczna analiza literatury przedmiotu oraz statystyczna analiza porównawcza.

Pierwszą część opracowania poświęcono teoretycznym podstawom integracji gospodarczej i monetarnej. Następnie przedstawiono zarys historyczny integracji krajów skandynawskich z Unią Europejską oraz Unią Gospodarczą i Walutową. W części trzeciej podjęto próbę oceny wpływu współczesnego kryzysu na spełnienie kryteriów konwergencji realnej i nominalnej przez kraje skandynawskie w okresie objętym analizą. Rozważania podsumowano implikacjami globalnego kryzysu dla perspektywy integracji Danii, Finlandii i Szwecji z UGiW.

\section{Teoretyczne podstawy integracji gospodarczej}

Integracja gospodarcza obejmuje środki zmierzające do eliminowania dyskryminacji między jednostkami gospodarczymi należącymi do różnych państw narodowych ${ }^{3}$. Oznacza powstawanie jednolitego, wewnętrznie powiązanego układu gospodarczego, obejmującego co najmniej dwa kraje ${ }^{4}$. Proces dokonuje się w wyniku stopniowej eliminacji granic ekonomicznych między niepodległymi państwami ${ }^{5}$. Wzajemne dostosowywanie struktur gospodarek oraz tworzenie się między nimi trwałych powiązań doprowadzają do zniesienia barier ograniczających współpracę gospodarczą ${ }^{6}$.

Teoria integracji gospodarczej koncentruje się głównie na analizie korzyści i kosztów, jakie mogą osiągnąć integrujące się gospodarki. W krótkim okresie występuje efekt kreacji handlu, wzrost konsumpcji i ekspansja handlu pomiędzy krajami członkowskimi. W długim okresie integracja przyczynia się do alokacji kapitału oraz wzrostu konkurencji na wspólnym rynku. Prowadzi do obniżenia cen i zwiększenia różnorodności towarów dostępnych dla konsumentów. W rezultacie następuje wzrost produkcji i dobrobytu?

Integracja początkowo dokonuje się na płaszczyźnie rynków. Na kolejnych etapach obejmuje stopniowo obszary polityki gospodarczej. Przejścia pomiędzy poszczególnymi stadiami mają charakter płynny, lecz nie zawsze dają się jednoznacznie

\footnotetext{
3 B. Balassa, The Theory of Economic Integration, Allen and Unwin, London 1961.

4 Z. Kamecki, Pojęcie i typy integracji gospodarczej, „Ekonomista” 1967, nr 1, s. 79-104.

5 W. Molle, Ekonomika integracji europejskiej: teoria, praktyka, polityka, Fundacja Gospodarcza NSZZ „Solidarność”, Gdańsk 1995.

6 J. Borowiec, Ekonomia integracji europejskiej, Wydawnictwo UE we Wrocławiu, Wrocław 2011.

7 R. Baldwin, C. Wyplosz, Economics of European Integration, McGraw-Hill, Columbus 2009.
} 
zdefiniować. Integracja przebiega w ramach międzynarodowych ugrupowań. Mają one za zadanie stwarzać instytucjonalne warunki do osiągnięcia ustalonego stanu zaawansowania. W zależności od stopnia zintegrowania gospodarek krajów członkowskich instytucjonalno-organizacyjne formy obejmują: strefę wolnego handlu, unię celną, wspólny rynek, unię gospodarczą i walutową oraz całkowitą integrację gospodarczą ${ }^{8}$.

Integracja gospodarcza wymaga pojawienia się czynników sprzyjających jej pogłębianiu. Za główną przyczynę uważa się postęp techniczny, który prowadzi do rozwoju coraz bardziej zróżnicowanej produkcji'. Motywy polityczne oraz potrzeba wzrostu gospodarczego krajów umożliwiają rozwój w ramach ugrupowania integracyjnego ${ }^{10}$. Otwartość i wzajemna współpraca członków pozwalają na wzrost integracji gospodarczej - im jest ona większa, tym istotniejsze korzyści przynosi wprowadzenie wspólnej waluty.

Teoria optymalnych obszarów walutowych (dalej TOOW) jest podstawowym narzędziem analizy procesów integracji walutowej. Teoria ta określa warunki, w jakich polityka gospodarcza może zostać pozbawiona możliwości użycia instrumentów polityki pieniężnej i kursowej, a mimo to zintegrowana gospodarka będzie miała zdolność do samoistnego przywracania równowagi. Trwałe spełnienie kryteriów funkcjonowania optymalnego obszaru walutowego oznacza zdolność akcesji państwa do unii monetarnej.

Optymalne obszary walutowe to regiony, w których korzyści z posiadania wspólnej waluty lub stosowania sztywnych kursów walutowych przewyższają koszty takiego rozwiązania ${ }^{11}$. Kraje tworzące unię monetarną powinny charakteryzować się wysokim stopniem wzajemnej otwartości oraz wielkością gospodarki ${ }^{12}$, a także zdywersyfikowaną i zbliżoną strukturą produkcji, popytu i eksportu ${ }^{13}$. Wysoki stopień integracji rynku dóbr, wysoka elastyczność płac i cen, znaczny zakres integracji fiskalnej, wysoka mobilność czynników produkcji oraz zsynchronizowane cykle koniunkturalne prowadzą do ustanowienia jednego obszaru walutowego ${ }^{14}$.

8 B. Balassa, op.cit.

9 W. Molle, Competitiveness, EMU and cohesion; Main challenges for post crisis EU policy, European Integration Process in the New Regional and Global Settings, 2012, s. 233-268.

10 J. Borowiec, op.cit.

11 R. Mundell, A Theory of Optimum Currency Areas, „American Economic Review” November 4, 1961, s. $657-665$.

12 R. McKinnon, Optimum Currency Areas and the European Experience, „Economics of Transition” 2002, Vol. 10(2), s. 343-364.

13 P. Kenen, The theory of optimum currency areas: an eclectic view, w: Monetary problems of the international economy, The University of Chicago Press, Chicago, London 1969.

14 M. Friedman, The Role of Monetary Policy, „The American Economic Review” March 1968, Vol. LVIII, No. 1, s. 1-17. 
Poszczególne nurty oparte na różnych i wykluczających się założeniach wpływają na jej niespójność. Krytycy tradycyjnej TOOW kładą większy nacisk na makroekonomiczne koszty niż na mikroekonomiczne korzyści. Podkreślają brak jednoznaczności co do kwestii, które kraje są częścią TOOW oraz brak możliwości zmierzenia niektórych kryteriów. Z tradycyjnej teorii optymalnych obszarów walutowych nie wynika, że konwergencja nominalna nie jest ani koniecznym, ani wystarczającym warunkiem utworzenia dobrze funkcjonującej unii walutowej ${ }^{15}$. Analiza kryteriów nie powinna dokonywać się na podstawie wszystkich warunków rozpatrywanych łącznie, ze względu na ich niezgodność ${ }^{16}$. Pomimo niespełnienia warunków członkostwa kraj może zdecydować się na przystąpienie do optymalnego obszaru walutowego, licząc na długookresową przewagę korzyści nad kosztami. Integracja monetarna usuwa przeszkody, które obniżają koszty transakcyjne oraz sprzyjają konwergencji strukturalnej ${ }^{17}$. W analizie procesów integracji walutowej w zbyt małym stopniu brana jest pod uwagę endogeniczność kryteriów. Dzięki korzyściom uzyskanym przez implementację wiarygodnej polityki monetarnej następuje wzrost integracji handlu oraz integracji finansowej, a także wzrost odporności obszaru na szoki zewnętrzne. Rosnąca integracja polityczna wzmacnia integrację finansową i synchronizację cykli koniunkturalnych ${ }^{18}$. Kraj nie musi spełnić kryteriów przed przystąpieniem do obszaru walutowego (ex ante). Członkostwo w obszarze walutowym - oznaczające wzrost stopnia integracji - doprowadzi do spełnienia wyjściowych kryteriów optymalnego obszaru walutowego (ex post $)^{19}$.

Kryteria przystąpienia do Unii Gospodarczej i Walutowej nie objęły części warunków postulowanych w teorii optymalnego obszaru walutowego. Wynikało to przede wszystkim $z$ uwarunkowań politycznych procesu integracji w Europie. Decyzja o utworzeniu UGiW miała głównie motywacje polityczne. Twórcy Traktatu z Maastricht zwrócili uwagę na makroekonomiczne kryteria zbieżności, mimo że TOOW wskazywała na kryteria mikroekonomiczne, jako najbardziej sprzyjające pełnej unii walutowej ${ }^{20}$.

15 P. De Grauwe, Unia walutowa, Polskie Wydawnictwo Ekonomiczne, Warszawa 2003.

16 G.S. Tavlas, Optimum - Currency - Area Paradoxes, „Review of International Economics” 2009, No. 17(3), s. 536-551.

17 F.P. Mongelli, New Views on the Optimum Currency Area Theory: What Is EMU Telling Us?, „ECB Working Paper", Frankfurt am Main 2002, No. 138; F.P. Mongelli, European economic and monetary integration and the optimum currency area theory, „Economic Papers” 302, European Commission, Brussels, February 2008.

18 P. Krugman, M. Obstfeld, International Economics: theory and policy, Addison Wesley, Boston 2000.

19 J. Frankel, A. Rose, The endogeneity of the optimum currency area criteria, „NBER Working Paper” 1996, No. 5700.

${ }_{20}$ Wybrane problemy integracji europejskiej, red. A. Stępniak, S. Umiński, A. Zabłocka, Wydawnictwo UG, Sopot 2009. 
Kraje Unii Europejskiej przeszły wiele etapów integracji: od strefy wolnego handlu, przez unię celną i wspólny rynek, do unii walutowej. Funkcjonowanie UE opiera się na wspólnych zasadach politycznych i gospodarczych państw członkowskich. Obecnie to najbardziej zaawansowana forma integracji gospodarczej na świecie. W świetle teorii nie jest jasne, czy postępująca integracja sprzyja globalizacji, czy prowadzi do dezintegracji gospodarki światowej.

\section{Zarys historyczny integracji krajów skandynawskich z Unią Europejską oraz Unią Gospodarczą i Walutową}

\subsection{Członkostwo Danii, Finlandii i Szwecji w UE}

Współpraca krajów skandynawskich została zapoczątkowana po utworzeniu Rady Nordyckiej ${ }^{21}$ w 1952 r. oraz Europejskiego Stowarzyszenia Wolnego Handlu ${ }^{22}$ w 1960 r.

Dania w 1970 r. rozpoczęła negocjacje w sprawie przystąpienia do Europejskiej Wspólnoty Gospodarczej. Rozmowy w latach 1970-1972 zakończyły się pozytywną oceną Komisji Europejskiej. Dnia 2 października 1972 r. mieszkańcy Danii opowiedzieli się za członkostwem ${ }^{23}$. Efektem było przystąpienie Królestwa Danii do Europejskiej Wspólnoty Gospodarczej 1 stycznia $1973 \mathrm{r}^{24}$

Położenie geopolityczne Finlandii przez lata wpływało na ograniczenie możliwości współpracy z organizacjami polityczno-ekonomicznymi ${ }^{25}$. W 1970 r. negocjacje z EWG doprowadziły do podpisania umowy znoszącej bariery celne. Złożenie wniosku o przyjęcie Finlandii do EWG było nadal niemożliwe. Wiązało się z naruszeniem obowiązującego Traktatu o Przyjaźni i Współpracy z ZSRR. Postępujące zmiany

21 Państwami założycielskimi Rady Nordyckiej były: Dania, Islandia, Norwegia i Szwecja. W późniejszych latach przystąpiły: Finlandia (1955 r.), Wyspy Owcze i Wyspy Alandzkie (1970 r.) oraz Grenlandia (1984 r.).

22 Konwencję sztokholmską podpisały: Austria, Dania, Norwegia, Portugalia, Szwajcaria, Szwecja i Wielka Brytania. Z czasem większość krajów wystąpiła z organizacji, wybierając członkostwo w Europejskiej Wspólnocie Gospodarczej. W latach 1986-1994 członkiem EFTA była Finlandia. Obecnie krajami członkowskimi EFTA są: Islandia, Liechtenstein, Norwegia i Szwajcaria. B. Piotrowski, Integracja Skandynawii. Od Rady Nordyckiej do Wspólnoty Europejskiej, Wydawnictwo Naukowe UAM, Poznań 2012.

23 Ponad 60\% Duńczyków opowiedziało się za członkostwem w EWG. Poparcie trudno było uzyskać wśród mieszkańców Grenlandii i Wysp Owczych. Ze względu na autonomię parlamenty Wysp Owczych (w 1974 r.) i Grenlandii (w 1985 r.) podjęły decyzję o pozostaniu poza EWG.

${ }^{24}$ W tym samym roku do EWG przystąpiły Wielka Brytania i Irlandia. 22 stycznia 1972 r. Dania, Irlandia, Norwegia i Wielka Brytania podpisały układy o przystąpieniu do EWG. 25 września 1972 r. Norwegowie odrzucili członkostwo podczas referendum. R. Matera, Integracja ekonomiczna krajów nordyckich, Wydawnictwo Adam Marszałek, Toruń 2001.

25 Wpływ Związku Radzieckiego sprawił, że Finlandia odmówiła przyjęcia planu Marshalla, odrzuciła projekt Unii Nordyckiej, nie mogła zostać państwem członkowskim lub stowarzyszonym EWG. 
polityczne w Europie Wschodniej wpłynęły na złożenie wniosku o członkostwo w UE w 1992 r. Układ akcesyjny został podpisany na wyspie Korfu 25 czerwca 1994 r. W tym samym roku ostateczną decyzję podjęło społeczeństwo podczas referendum ${ }^{26}$.

Droga Szwecji do UE była podobna do fińskiej - jednak Szwecja nie znajdowała się pod presją Związku Radzieckiego. Negocjacje w sprawie członkostwa rozpoczęły się 10 listopada 1970 r. Po opublikowaniu planu Wernera rząd szwedzki ogłosił, że z powodu zaistniałych okoliczności członkostwo w UE nie jest możliwe. Kolejną gotowość Szwecja zgłosiła w grudniu 1990 r., a układ akcesyjny podpisała 24 czerwca 1994 r. Po ratyfikacji przez Parlament Europejski i rząd decyzję w sprawie członkostwa podjęło społeczeństwo podczas referendum ${ }^{27}$.

Finlandia i Szwecja przystąpiły do Unii Europejskiej 1 stycznia 1995 r. $^{28}$

W latach 90. XX w. rodziły się dylematy związane z integracją europejską. Historyczne znaczenie miało ogłoszenie w 1991 r. Traktatu z Maastricht ${ }^{29}$. Podczas szczytu w Edynburgu 12 grudnia 1992 r. rząd duński wynegocjował uregulowania związane z tym traktatem. Dzięki nim Królestwo Danii zostało zwolnione z trzeciego etapu integracji.

Proces integracji krajów skandynawskich z UE dokonywał się na zasadzie przyzwolenia społecznego. W Szwecji w kwietniu 1998 r., w Danii w maju 1998 r. oraz w Finlandii w czerwcu 1998 r. społeczeństwo zadecydowało o ratyfikacji Traktatu z Amsterdamu. Argumentami za przyjęciem była możliwość rozszerzenia Unii Europejskiej oraz gwarancja zachowania wyjątków z poprzedniego traktatu - w przypadku Danii. Podkreślano, że regulacje mogą być zmienione w drodze referendum. Dania, Finlandia i Szwecja potwierdzały, że rozszerzenie Wspólnoty jest wyzwaniem dla Europy. Krajom tym zależało na pogłębianiu integracji w tzw. wymiarze bałtyckim, północnym i wschodnim ${ }^{30}$.

Dania, Finlandia i Szwecja w 1995 r. uzyskały status obserwatorów Porozumienia z Schengen. Opóźnienie w jego podpisaniu wynikało z niechęci społeczeństwa, propozycji przystąpienia Islandii i Norwegii na specjalnych warunkach, a także

26 Podczas referendum 16 października 1994 r. połowa ludności Finlandii opowiedziała się za przystąpieniem do UE. Wyspy Alandzkie przystąpiły do UE wraz z Finlandią w 1995 r. Obecnie status Wysp Alandzkich jest gwarantowany międzynarodowo przez traktat akcesyjny do UE. J. Kiander, Macroeconomic policy and performance in the Nordic EU countries in the 1990's, „Ezoneplus Working Paper” 2003, No. 17B.

${ }^{27}$ Referendum odbyło się 13 listopada 1994 r. Ponad połowa mieszkańców Szwecji zagłosowała za członkostwem w UE. R. Matera, op.cit.

${ }^{28}$ Do Unii Europejskiej w tym samym roku przystąpiła Austria.

${ }^{29}$ Irlandia, Francja i Dania zastrzegły, że oprócz ratyfikacji przez parlamenty zostanie przeprowadzone referendum w sprawie przyjęcia Traktatu z Maastricht.

30 Przystąpienie Estonii, Łotwy i Litwy do UE było jednym z tematów podczas prezydencji Danii w Radzie Unii Europejskiej w 1993 r. Wymiar Północny został zainicjowany w 1997 r. przez rząd Finlandii. Projekt Partnerstwa Wschodniego został zapoczątkowany działaniami Polski, przy wsparciu Szwecji w 2009 r. 
zniesienia kontroli paszportowej na wewnętrznych granicach Unii oraz uszczelnienia granicy wschodniej (fińsko-rosyjskiej). Ostatecznie kraje skandynawskie przystąpiły do strefy Schengen 25 marca $2001 \mathrm{r}^{31}$

Początki XXI w. to czas przemian w Unii Europejskie i dostosowań krajów skandynawskich do wymogów unijnych. Reformujące Traktaty z Nicei i Lizbony głównie dotyczyły zasad ustalania składu Komisji Europejskiej, podziału miejsc w Parlamencie Europejskim oraz sposobu podejmowania decyzji w Radzie Unii Europejskiej ${ }^{32}$. Według oceny rządów Danii, Finlandii i Szwecji obydwa traktaty zostały ratyfikowane jednomyślnie, ponieważ uwzględniały najważniejsze interesy krajów skandynawskich.

Postęp integracji Danii, Finlandii i Szwecji z Unią Europejską należy oceniać pozytywnie, lecz nie we wszystkich dziedzinach, tj. słabiej w polityce monetarnej i walutowej. Przebiegał on w szybkim tempie dzięki poparciu społeczeństwa oraz członkostwu we wcześniejszych organizacjach międzynarodowych. Pomimo osiągnięć proces ten nie jest jeszcze zakończony. Czy będzie się pogłębiał, decydować będzie wola rządu i obywateli poszczególnych krajów.

\subsection{Przyczyny przyjęcia odmiennych rozwiązań integracji krajów skandynawskich z UGiW}

Wprowadzenie w 1999 r. waluty euro było kolejnym etapem integracji, mającym wymiar polityczno-gospodarczy ${ }^{33}$. Wiązało się z unifikacją polityki pieniężnej oraz koordynacją polityki budżetowej państw członkowskich. Warunki uczestnictwa w trzecim etapie Unii Gospodarczej i Walutowej zawarto w Traktacie o Unii Europejskiej. Zapisano w nim, że każdy kraj Unii Europejskiej ma prawo i obowiązek uczestnictwa w UGiW. Członkostwo nie jest automatyczne, a każde państwo musi spełnić kryteria konwergencji nominalnej ${ }^{34}$. Wymieniono warunek konwergencji prawnej,

\footnotetext{
${ }^{31}$ Islandia i Norwegia wraz z Danią, Finlandią i Szwecją należą do Nordyckiej Unii Paszportowej, od 1952 r. - po utworzeniu Rady Nordyckiej. J. Kiander, op.cit.

${ }^{32}$ Na mocy Traktatu z Nicei w latach 2004-2014 Szwecja dysponuje dziesięcioma głosami w Radzie UE, natomiast Dania i Finlandia posiadają po siedem głosów. Na mocy Traktatu z Lizbony prezydencja Rady UE ma znaczenie honorowe. W latach 1973-2014 Dania sprawowała prezydencję siedem razy, natomiast Finlandia i Szwecja - po dwa razy.

33 Początki tworzenia wspólnego obszaru walutowego to 1969 r. Powołana komisja pod przewodnictwem P. Wernera miała za zadanie opracowanie planu utworzenia unii walutowej w ramach EWG. Plan Wernera nie został zrealizowany. W 1988 r. pod kierownictwem J. Delorsa utworzono komitet, którego zadaniem było opracowanie programu tworzenia unii. Raport komitetu Delorsa stał się podstawą do sformułowania artykułów dotyczących współpracy walutowej między państwami członkowskimi. Podpisany 7 lutego 1992 r. Traktat z Maastricht określił cel, którym było przyjęcie wspólnej waluty, wyznaczył terminy tworzenia oraz warunki uczestnictwa w Unii Gospodarczej i Walutowej. P. De Grauwe, Unia walutowa, op.cit.

${ }^{34}$ Kryteria przystąpienia do UGiW według Protokołu o kryteriach konwergencji dołączonego do Traktatu o UE:
} 
czyli dostosowania przepisów wewnętrznych regulujących status, cel i funkcjonowanie banku centralnego do zasad wynikających z TUE. Spośród piętnastu państw UE Komisja Europejska w 1998 r., po zweryfikowaniu spełnienia kryteriów zbieżności, wskazała jedenaście państw, które mogły przystąpić do UGiW. Kraje, które pozostały poza obszarem euro, tj. Dania i Wielka Brytania, skorzystały z prawa opt-out, przyznanego na mocy Traktatu z Maastricht. Natomiast Szwecja i Grecja nie spełniły w wystarczającym stopniu kryteriów konwergencji ${ }^{35}$.

Z historycznego punktu widzenia kraje skandynawskie zdobyły doświadczenie w unifikacji waluty. Wynika ono z uczestniczenia w Skandynawskiej Unii Monetarnej na przełomie XIX i XX w. ${ }^{36} \mathrm{~W}$ momencie tworzenia Unii Gospodarczej i Walutowej kraje te wybrały odmienne rozwiązania integracyjne. Spośród tych krajów Finlandia od 1999 r. jest członkiem UGiW, natomiast Dania i Szwecja znajdują się poza strefą euro ${ }^{37}$.

Pozostawanie Danii poza głównym procesem pogłębiania integracji europejskiej nie oznaczało odejścia od wypełniania kryteriów zbieżności. Dania spełniła kryteria konwergencji nominalnej, a bank centralny stał się niezależny. Dodatkowo społeczeństwo duńskie nie zaakceptowało w całości Traktatu z Maastricht, odrzucając w 2000 r. możliwość przystąpienia do strefy euro ${ }^{38}$. Dania przystąpiła do systemu ERM II, w paśmie wahań 2,25\%, który stał się tzw. poczekalnią dla kraju przed pełnym członkostwem w UGiW.

1) Wskaźnik inflacji nie powinien być wyższy niż 1,5 pkt. proc. od średniej stopy inflacji odnotowanej $\mathrm{w}$ trzech krajach unijnych o najniższym poziomie tego wskaźnika w roku poprzedzającym weryfikację.

2) Poziom długookresowych stóp procentowych, w ciągu roku przed oceną, nie może przekraczać więcej niż 2 pkt. proc. stopy procentowej występującej w trzech krajach UE, które odnotowały najniższą stopę inflacji.

3) Maksymalny poziom deficytu budżetowego krajów ubiegających się o członkostwo w UGiW może wynosić 3\% PKB, z zastrzeżeniem, że wyjątkowo może być zaakceptowany poziom wyższy.

4) W kraju kandydującym musi zostać zredukowane zadłużenie publiczne do wielkości $60 \%$ PKB w roku poprzedzającym ocenę.

5) Waluta kraju kandydującego musi uczestniczyć w mechanizmie kursowym Europejskiego Systemu Walutowego przez okres dwóch lat.

35 A. Królikowska, Czy warto być poza Unia Monetarna - studium przypadku Wielkiej Brytanii, Danii i Szwecji, „Europejska Integracja Monetarna od A do Z”, „Bank i Kredyt” 2008, nr 4.

36 Skandynawska Unia Monetarna w latach 1873-1914 była umową ekonomiczną pomiędzy Danią, Szwecją i Norwegią. Formalnie odrębne waluty tych trzech krajów stały się równoprawnym środkiem płatniczym na terenie całej Skandynawii poprzez związanie ich z kursem złota oraz zastosowanie wymienialności 1:1. Efektem Unii było ujednolicenie nazw walut, tj. zastąpienie dotychczasowych nazw własnych walut słowem „korona”. J. Borowiec, op.cit.

37 Integracja europejska, red. A. Marszałek, Polskie Wydawnictwo Ekonomiczne, Warszawa 2004; L. Nyberg, After the crisis - new thoughts on monetary policy, Speech of the Sveriges Riksbank, „BIS Review” No. 1640, Bank for International Settlements, Basel 2010.

3828 września 2000 r. w Danii przeprowadzono referendum, w którym wzięło udział 87\% uprawnionych do głosowania. Za wprowadzeniem euro opowiedziało się 47\% głosujących obywateli, a przeciwko było $53 \%$. 
W przeciwieństwie do Danii i Wielkiej Brytanii, Szwecja nie miała prawa do klauzuli opt-out ${ }^{39}$. O objęciu Szwecji derogacją przesądziło nie tyle niespełnienie wszystkich kryteriów konwergencji, ile brak woli politycznej do ich wypełnienia. W Szwecji od początku ustanawiania UGiW nie było zainteresowania unifikacją polityki monetarnej i walutowej. Podobnie jak w przypadku Danii, negatywne stanowisko wobec euro wynikało $\mathrm{z}$ niechęci społeczeństwa do pogłębiania integracji ${ }^{40}$. Wobec tego rząd zdecydował, iż kraj nie przystąpi 1 stycznia 1999 r. do III etapu UGiW oraz ERM II. Przesłanką negatywnego stosunku przystąpienia Szwecji do UGiW była chęć utrzymania niezależnego banku centralnego - jednego z najstarszych banków centralnych na świecie ${ }^{41}$.

W Finlandii poglądy na temat tworzenia Unii Gospodarczej i Walutowej były odmienne. Według rządu unia walutowa była ważnym instrumentem, wypracowanym wobec procesu globalizacji. Wypełnienie kryteriów konwergencji świadczyło o właściwej polityce monetarnej i walutowej. Dnia 17 kwietnia 1998 r. rząd zdecydował o przystąpieniu do III etapu tworzenia Unii Gospodarczej i Walutowej. Finlandia - jedyny kraj skandynawski - znalazła się wśród 11 państw mających wprowadzić wspólną walutę. Wprowadzenie euro na terenie Finlandii odbyło się przy poparciu społecznym ${ }^{42}$.

Dania, Finlandia i Szwecja przed przystąpieniem do UGiW spełniły kryteria dotyczące członkostwa. W przeciwieństwie do Finlandii, wśród przyczyn odrzucenia euro w Danii i Szwecji przeważało negatywne nastawienie społeczeństwa. Wysoki poziom rozwoju społeczno-gospodarczego tych krajów sprawił, że możliwość poniesienia kosztów społecznych i politycznych przeważyła nad korzyściami wynikającymi z przystąpienia do strefy euro.

39 W momencie ustanawiania Traktatu z Maastricht Szwecja nie była członkiem EWG. Podstawą objęcia Szwecji derogacją - niezakwalifikowania do uczestnictwa w III etapie UGiW - była decyzja Rady UE podjęta na podstawie Traktatu.

4014 września 2003 r. w Szwecji odbyło się referendum w sprawie przystąpienia do UGiW. Ponad połowa mieszkańców opowiedziała się przeciwko wprowadzeniu euro.

${ }^{41}$ M. Jerneck, Sveriges inflytande i EU efter krisen, „Svenska institutet för europapolitiska studier, Europapolitisk Analys" 2013, No. 10, s. 1-12.

${ }^{42}$ W latach 1997-1998 ponad połowa mieszkańców Finlandii opowiadała się za przyjęciem euro jako prawnego środka płatniczego w kraju. R. Matera, op.cit. 


\section{Konwergencja gospodarcza Danii, Finlandii i Szwecji w latach 1999-2013}

\subsection{Stopień realizacji kryteriów konwergencji nominalnej na tle państw członkowskich}

W roku 1999 Finlandia przystąpiła do strefy euro, Dania automatycznie została objęta klauzulą opt-out, a Szwecja przyjęła status państwa członkowskiego z derogacją ${ }^{43}$.

Głównym celem konwergencji nominalnej jest ocena zdolności gospodarki do funkcjonowania bez zakłóceń w unii monetarnej - mimo ograniczonej realizacji polityki pieniężnej i budżetowej. Według Traktatu z Maastricht przystąpienie do Unii Gospodarczej i Walutowej następuje po spełnieniu tzw. kryteriów z Maastricht ${ }^{44}$. Oprócz niezależności banku centralnego kraje kandydujące muszą spełnić pięć warunków, tj. dotyczące: stóp procentowych, stabilności cen, fiskalne (deficytu budżetowego oraz zadłużenia publicznego) oraz kursowe ${ }^{45}$.

W krajach skandynawskich oraz UGiW kryterium długoterminowych stóp procentowych było jedynym spełnionym od $1998 \mathrm{r}$. W latach 1998-2013 poziomy długoterminowych stóp procentowych w Danii, Szwecji i Finlandii oraz średnie w krajach UGiW i UE- $12^{46}$ kształtowały się poniżej wartości referencyjnych. Konwergencja ta wynikała z oczekiwania i zapewnienia stabilności cen. Znalazło to odzwierciedlenie w spadku rentowności długoterminowych papierów skarbowych (por. rysunek 1).

W latach 1998-2007 stopy inflacyjne utrzymywały się na poziomie niższym lub równym wartości referencyjnej. Wynikało to ze stabilizacji tempa wzrostu cen, jaka dokonała się w ramach realizacji strategii polityki pieniężnej banków centralnych ${ }^{47}$. Początek globalnego kryzysu wpłynął na zmiany poziomu cen. Wzrost inflacji, a następnie jej spadek na przełomie lat 2007 i 2008 był cechą wspólną wszystkich krajów. Ryzyko przekroczenia wartości referencyjnej urzeczywistniło się na przełomie lat 2008 i 2009, gdy stopy inflacji wyniosły ponad 3\%. W efekcie, w $2010 \mathrm{r}$. poziomy

43 L. Heikensten, Monetary policy and potential growth, Speech of the Sveriges Riksbank, „BIS Review” No. 16, Bank for International Settlements, Basel 2003; M.A. Kose, E.S. Prasad, M.E. Terrones, Financial Integration and Macroeconomic, Volatility, „IMF Working Paper” 2003, No. 03/50.

44 Początkowo kryteria zapisane były w Traktacie o Unii Europejskiej. W wyniku wejścia w życie Traktatu z Lizbony znalazły się one w art. 140 tego traktatu.

45 P. De Grauwe, The Financial Crisis and the Future of the Eurozone, „Bruges European Economic Policy Briefings" 2010, No. 21.

46 Określenie UE-12 rozumiane jest w niniejszej pracy jako grupa wybranych krajów Unii Europejskiej, tj. Austria, Belgia, Francja, Grecja, Hiszpania, Holandia, Irlandia, Luksemburg, Niemcy, Portugalia, Wielka Brytania oraz Włochy - dane uśrednione.

47 W Danii obowiązuje kotwica walutowa; w Szwecji cel inflacyjny na poziomie 2\% \$1\%; w Finlandii cel inflacyjny Europejskiego Banku Centralnego na poziomie blisko, ale poniżej $2 \%$. 
HICP w krajach skandynawskich oraz średnie dla krajów UGiW i UE-12 przekroczyły wartości referencyjne o blisko $1 \%$ (por. rysunek 2).

\section{Rysunek 1. Ocena wypełnienia kryterium długoterminowych stóp procentowych} w UGiW, Danii, Finlandii, Szwecji i UE-12 w latach 1998-2013

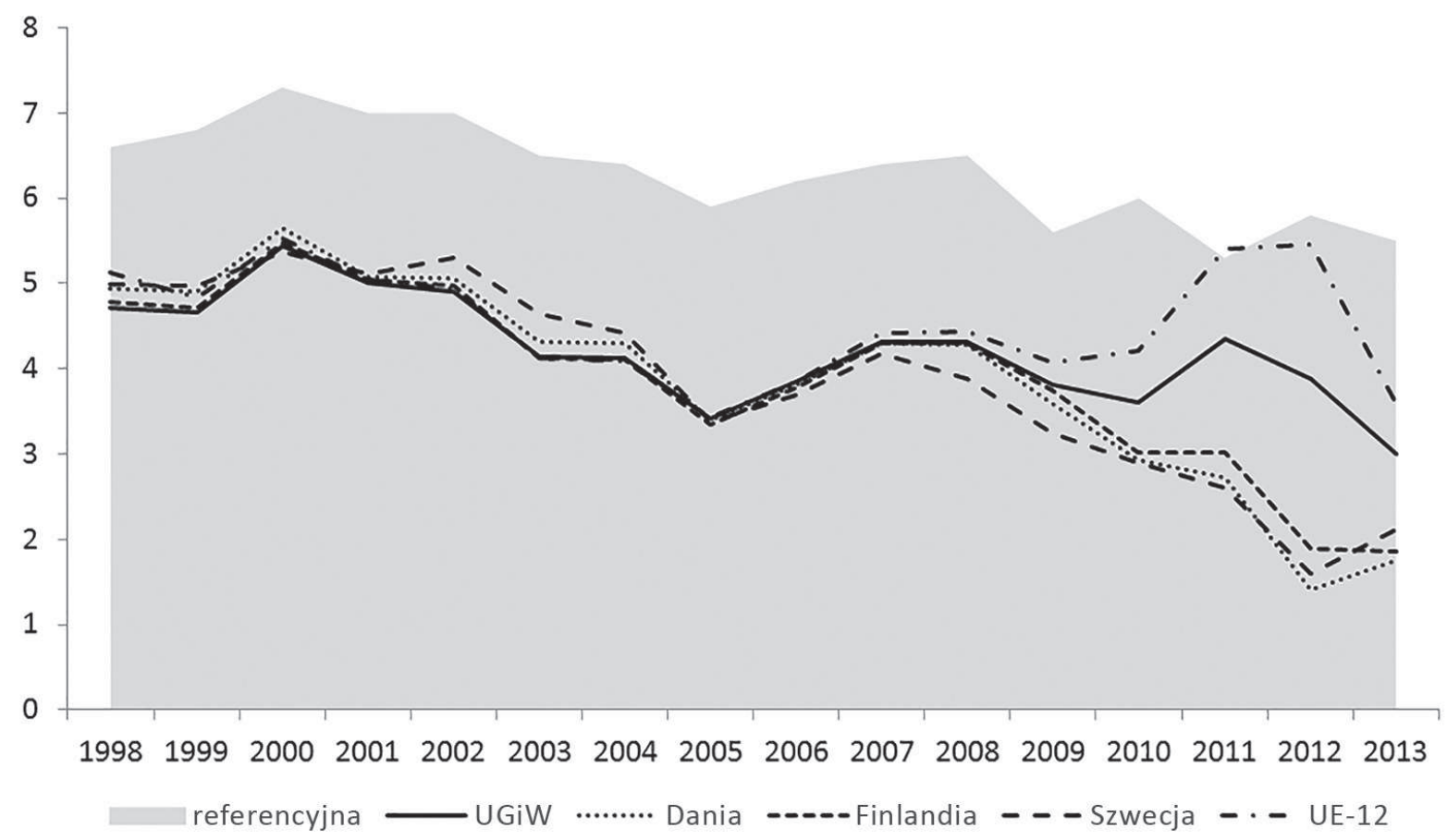

Źródło: Opracowanie własne na podstawie danych statystycznych Eurostatu.

\section{Rysunek 2. Zmiany HICP w UGiW, Danii, Finlandii, Szwecji i UE-12 w porównaniu} Z wartością referencyjną w latach 1998-2013

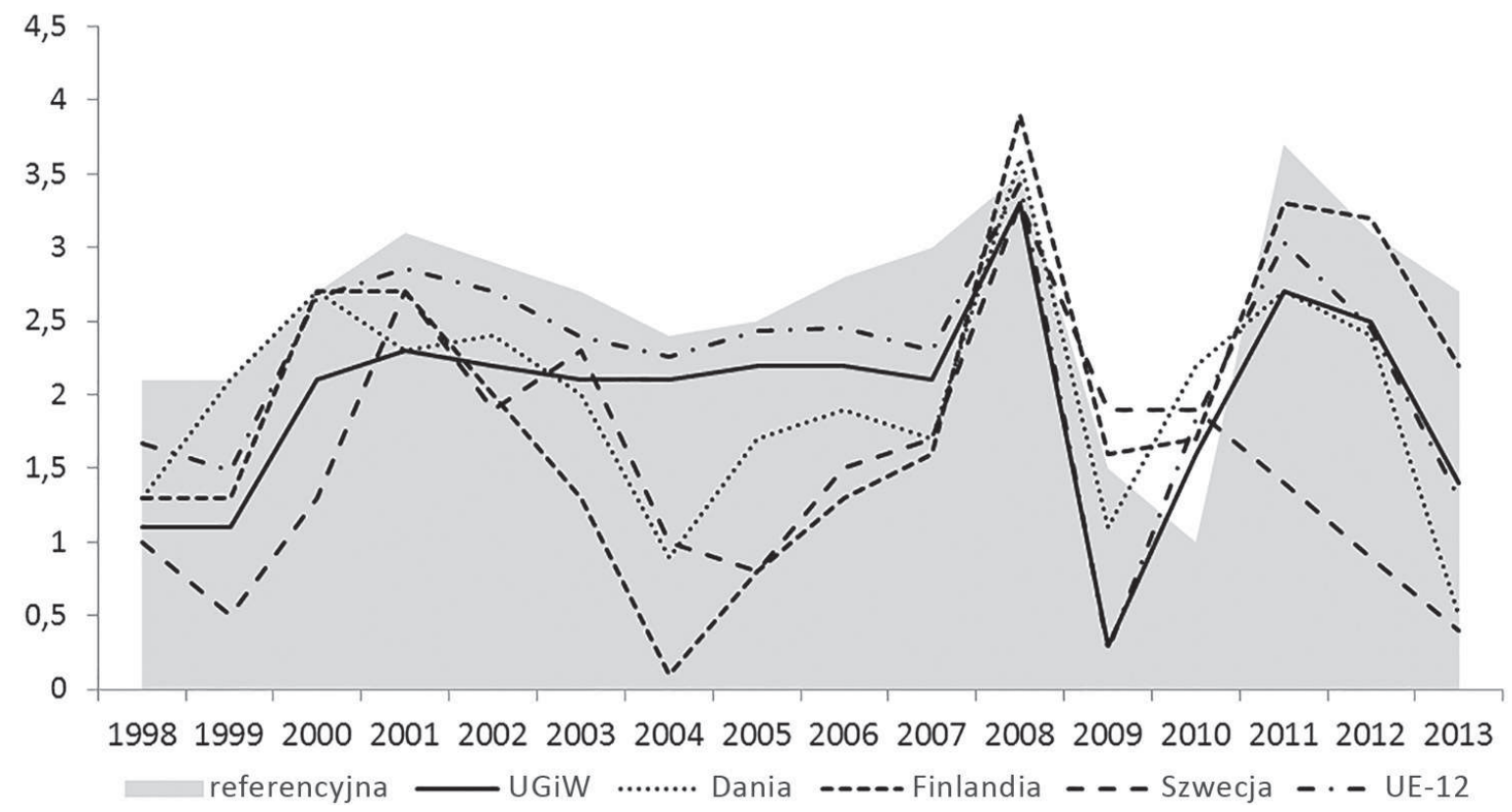

Źródło: Opracowanie własne na podstawie danych statystycznych Eurostatu. 
W badanym okresie kraje skandynawskie charakteryzowały się dobrą sytuacją w finansach publicznych. Pod względem wielkości deficytu dane dla tych krajów przedstawiały się bardzo dobrze - odnotowywano nadwyżki w budżecie do $2008 \mathrm{r}$. W latach 1998-2008 wielkość deficytu budżetowego kształtowała się na poziomie nieprzekraczającym kryterium konwergencji. Globalny kryzys finansowy doprowadził do zmian w deficycie finansów publicznych. Średnie dla krajów UE-12 i UGiW przekroczyły wartości referencyjne, w przeciwieństwie do krajów skandynawskich, które nadal spełniały kryterium ${ }^{48}$ (por. rysunek 3).

\section{Rysunek 3. Deficyt budżetowy (\% PKB) w UGiW, Danii, Finlandii, Szwecji i UE-12 w latach 1998-2012}

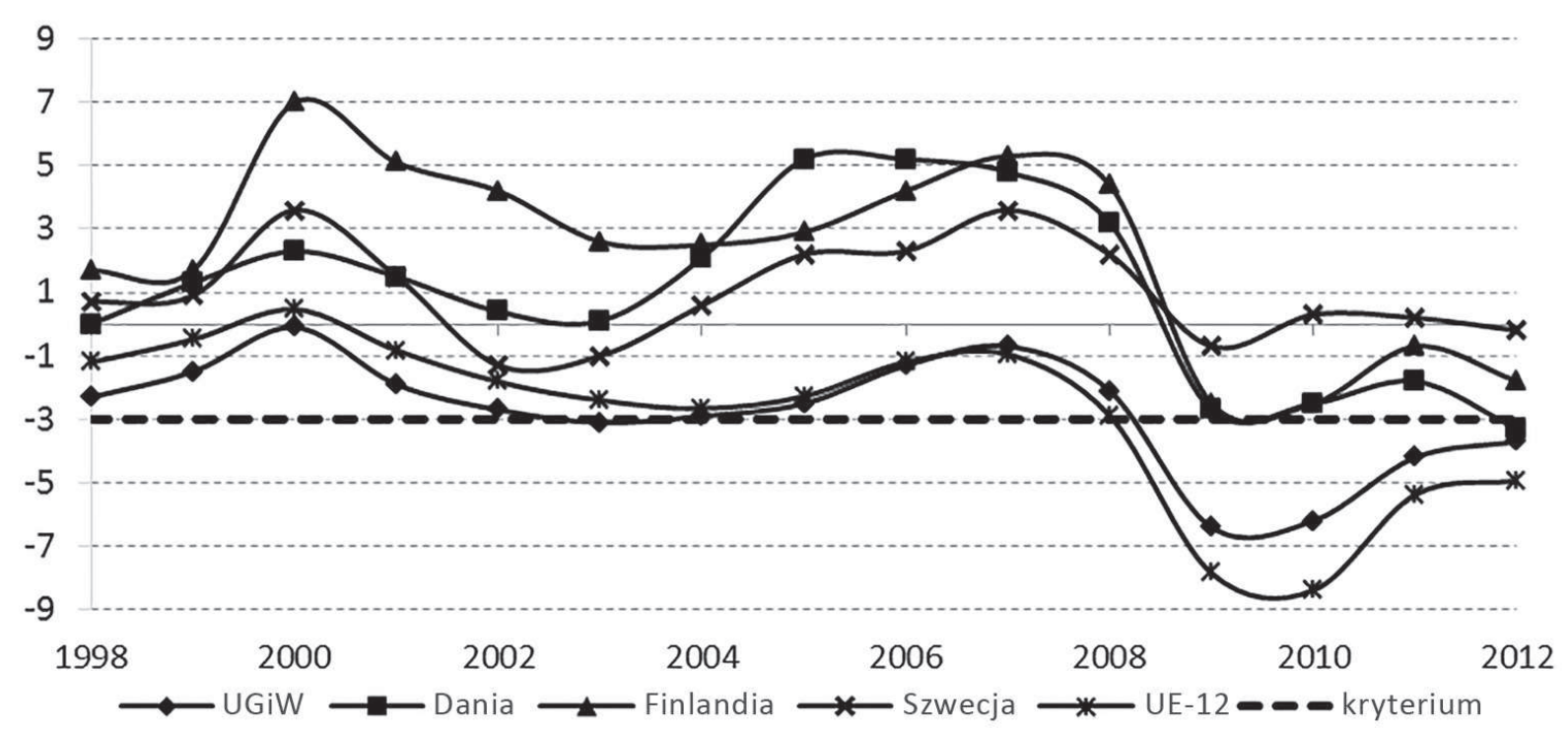

Źródło: Opracowanie własne na podstawie danych statystycznych Eurostatu.

W momencie tworzenia unii walutowej Dania i Szwecja nie spełniły kryterium długu publicznego. Warunek ten spełniły tylko trzy kraje (Finlandia, Francja i Luksemburg), więc Komisja Europejska obniżyła kryterium przystąpienia do strefy euro. W krajach skandynawskich w latach 2000-2012 dług publiczny nie przekroczył 60\% $\mathrm{PKB}$ - w przeciwieństwie do średnich dla krajów UGiW oraz UE-12. Globalny kryzys finansowy oraz spowolnienie gospodarcze doprowadziły do pogorszenia się polityki fiskalnej, a w rezultacie do wzrostu długu publicznego. Potwierdziło to wątpliwości

48 W kontekście globalnego kryzysu finansowego i spowolnienia gospodarczego w 2010 r. Dania i Finlandia zostały objęte procedurą nadmiernego deficytu. Natomiast w 2013 r. spośród państw członkowskich UE Finlandia i Szwecja nie zostały objęte procedurą nadmiernego deficytu. 
Europejskiego Banku Centralnego co do trwałej zdolności spełniania kryterium fiskalnego (por. rysunek 4).

Rysunek 4. Wielkość długu publicznego (\% PKB) w UGiW, Danii, Finlandii, Szwecji i UE-12 w latach 1998-2012

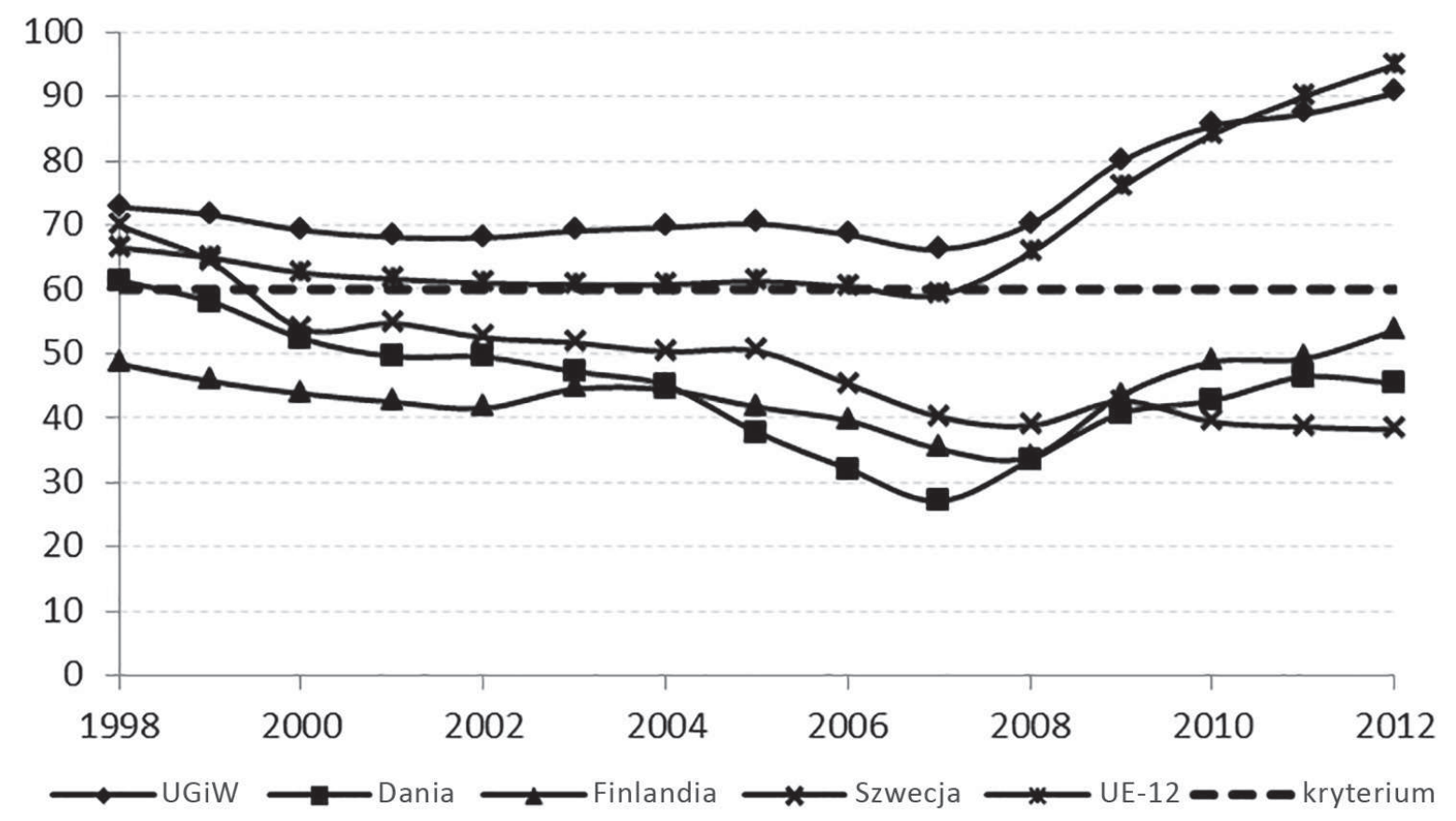

Źródło: Opracowanie własne na podstawie danych statystycznych Eurostatu.

Warunkiem przystąpienia Finlandii do UGiW było wprowadzenie marki fińskiej do ERM, co stało się 14 października 1996 r. Marka była ostatnią walutą, która znalazła się w tym systemie, lecz szybko została uznana za stabilną. Finlandia spełniła kursowe kryterium, a marka fińska została zastąpiona euro ${ }^{49}$.

Wprowadzony w 1999 r. Mechanizm Kursu Walutowego II (ERM II) zastąpił pierwotny ERM, a korona duńska stała się jego częścią. Bank centralny Danii ograniczył maksymalne dopuszczalne odchylenia kursu walutowego w ERM II w stosunku do kursu centralnego euro z $\pm 15 \%$ do $\pm 2,25 \%$. Dania poprzez uczestnictwo w mechanizmie spełniła kryterium kursowe $e^{50}$.

Korona szwedzka nie była uwzględniana w tzw. wężu walutowym w 1979 r. Szwecja została włączona do pierwszej grupy państw, które nie mogły przystąpić do unii

${ }^{49}$ Kurs wymiany w 1999 r. wynosił 1 euro $=$ 5,94573 marki fińskiej (oprac. własne na podstawie danych Eurostatu).

50 Według danych Eurostatu w latach 1998-2013 kurs euro do korony duńskiej wahał się w przedziale 7,43-7,50. Globalny kryzys finansowy nie wpłynął na stabilność korony duńskiej i w 2009 r. kurs EUR/DKK wyniósł 7,45 (oprac. własne na podstawie danych Eurostatu). 
monetarnej, ponieważ nie należała do pierwszego ERM. Bank centralny Szwecji przyjął politykę płynnego kursu walutowego, nie przystępując do ERM II. Konsekwencją takiej polityki było niespełnienie kryterium zbieżności ${ }^{51}$.

Konwergencja prawna obejmuje ocenę zgodności ustawodawstwa krajowego z traktatem oraz Statutem Europejskiego Systemu Banków Centralnych i EBC ${ }^{52}$. Kryterium to spełniły Dania i Finlandia. Komisja Europejska oraz Europejski Bank Centralny w 1999 r. nie stwierdziły niezgodności w zakresie niezależności banku centralnego Danii. W Finlandii statut banku centralnego został zmieniony w 1999 r. zgodnie z traktatem. Największe nieprawidłowości zostały odnotowane w Szwecji. Prawo szwedzkie nie spełniło wymagań dotyczących niezależności banku centralnego oraz zintegrowania z UGiW. Szwecja, jako państwo członkowskie UE objęte derogacją, zobowiązana jest w całości spełnić wymagania traktatu. Władze szwedzkie jednak nie podejmują działań legislacyjnych w celu usunięcia niezgodności.

\subsection{Stopień realizacji kryteriów konwergencji realnej na tle państw członkowskich}

Spełnienie kryteriów konwergencji nominalnej i prawnej jest pochodną stopnia konwergencji realnej ${ }^{53}$. Od poziomu jej spełnienia - przede wszystkim w jakim stopniu gospodarka kraju jest podobna do gospodarki strefy euro - zależą zagrożenia i szanse związane z przyjęciem wspólnej waluty. Konwergencja realna wpływa pozytywnie na możliwość wypełnienia kryteriów konwergencji nominalnej, przez co potwierdza poziom faktycznego przygotowania kraju do przyjęcia wspólnej waluty ${ }^{54}$.

Aspektem konwergencji realnej, mającym znaczenie dla bilansu kosztów i korzyści z członkostwa w strefie euro, jest korelacja cykli koniunkturalnych. Strukturalne podobieństwo gospodarek Danii, Finlandii i Szwecji do gospodarek strefy euro oraz podobny przebieg cykli koniunkturalnych wpływają na wysoki stopień szeroko rozumianej konwergencji realnej tych krajów. Współczynniki korelacji tempa wzrostu

51 Kurs euro do korony szwedzkiej w latach 1998-2013 kształtował się na poziomie 8,45-10,62. Na stabilność korony szwedzkiej wpłynął globalny kryzys finansowy. W 2009 r. kurs EUR/SEK wyniósł 10,62 (oprac. własne na podstawie danych Eurostatu).

52 W kraju kandydującym do UGiW muszą być spełnione: niezależność funkcjonalna, instytucjonalna, personalna i finansowa banku centralnego, spójność celów banku centralnego oraz zapewnienie przez kraj członkowski zgodności legislacyjnej.

${ }^{53}$ Kryteria konwergencji realnej informują o wyrównywaniu się poziomów wielkości realnych pomiędzy gospodarkami. Wyrażane są za pomocą wskaźników ilustrujących stan sfery realnej kraju. W analizie stopnia spełnienia kryteriów konwergencji realnej brane są pod uwagę m.in. wielkość dochodu narodowego per capita, saldo handlu zagranicznego, poziom konsumpcji czy nakłady inwestycyjne.

54 A. Czarczyńska, K. Śledziewska, Teoria europejskiej integracji gospodarczej, Wydawnictwo C.H. Beck, Warszawa 2003; F.S. Mishkin, Monetary Policy Strategy: Lessons from the Crisis, „NBER Working Paper” 2011, No. 16755. 
realnego PKB krajów skandynawskich - w latach 1998-2013 - z krajami UGiW wyniosły: 0,951 - Dania; 0,982 - Finlandia; 0,878 - Szwecja, natomiast z krajami UE-12 wyniosły: 0,917 - Dania; 0,931- Finlandia; 0,805 - Szwecja ${ }^{55}$. Na zróżnicowanie wyników wpłynął odmienny wybór realizacji polityki gospodarczej przez te kraje. W przypadku Danii usztywnienie kursu korony duńskiej względem euro wpłynęło na wzrost zbieżności. Przyjęcie wspólnej waluty w Finlandii przyspieszyło proces upodobniania się gospodarki do UGiW. Derogacja Szwecji zwiększyła zróżnicowanie w zakresie podobieństwa względem wspólnego obszaru walutowego.

Kraje skandynawskie to kraje wysoko rozwinięte. W analizowanym okresie stopa wzrostu PKB per capita oraz poziom PKB per capita w Danii, Finlandii i Szwecji były na zbliżonym poziomie do średnich krajów UGiW oraz UE-12. Od momentu powstania strefy euro kryzys finansowy zapoczątkowany w $2007 \mathrm{r}$. najdotkliwiej ujawnił się w 2009 r. Jego przebieg w krajach UE był zróżnicowany i doprowadził do zakłóceń makroekonomicznych, przenosząc się na sferę realną. Mimo to wyniki gospodarcze Danii i Szwecji na tle innych wysoko rozwiniętych gospodarek Unii Europejskiej - w tym Finlandii - były lepsze (por. rysunek 5).

Z przeprowadzonych badań wynika, że między krajami skandynawskimi i krajami UGiW oraz UE-12 występują różnice. Dla okresu 1998-2013 poziomy współczynników zmienności procentowego udziału eksportu, importu, konsumpcji, inwestycji, badań i rozwoju oraz długu publicznego w produkcie krajowym brutto były rozbieżne. W Danii i Szwecji - w stosunku do krajów UGiW oraz UE-12 - wystąpiły większe różnice pomiędzy analizowanymi współczynnikami niż w Finlandii. Dania i Szwecja, pozostające poza ugrupowaniem, wskazały na występowanie dywergencji. W przypadku Finlandii, kraju członkowskim UGiW, analiza dowiodła zbieżności z krajami strefy euro (por. rysunek 6).

W krajach skandynawskich na konwergencję realną i nominalną wpłynęły: liberalizacja gospodarcza, otwartość na wymianę międzynarodową oraz postępująca integracja w ramach Unii Europejskiej. Dania, Finlandia i Szwecja charakteryzowały się: jednorodnością gospodarczą, podobnie działającymi mechanizmami rynkowymi, przyjętymi regulacjami prawnymi, własnościowymi, instytucjonalnymi i infrastrukturalnymi. Doświadczenia krajów członkowskich UGiW oraz krajów skandynawskich - ze współczesnego kryzysu finansowego - wykazały, że w procesie integracji walutowej istotne jest osiągnięcie konwergencji realnej, a nie tylko trwałe wypełnienie kryteriów konwergencji nominalnej i prawnej.

55 Oprac. własne na podstawie danych Eurostatu. 
Rysunek 5. PKB per capita (ceny bieżące w euro) i zmiana PKB per capita (w \%) w UGiW, Danii, Finlandii, Szwecji i UE-12 w latach 1999, 2007, 2009, 2012
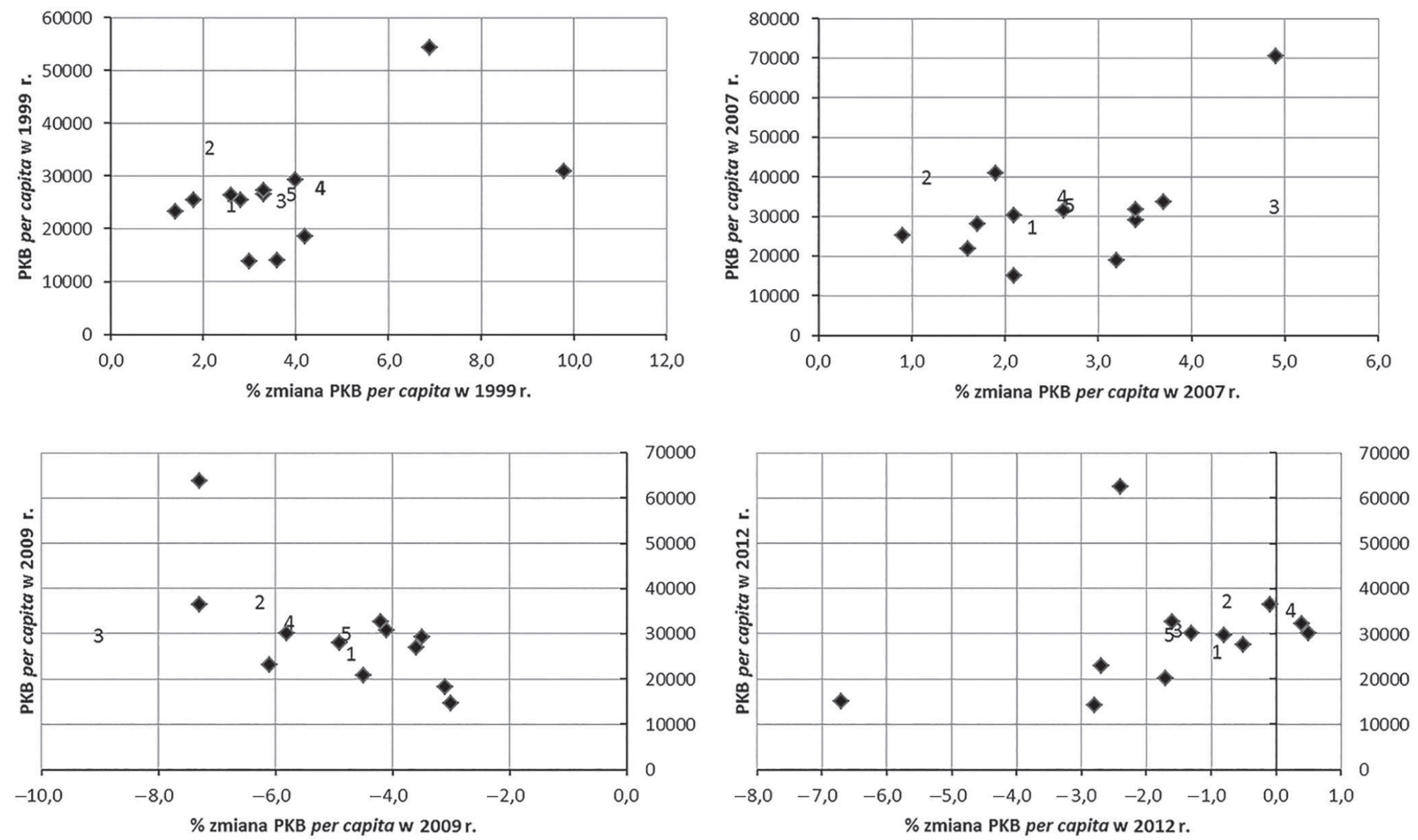

$$
\text { 1-UGiW 2-Dania 3-Finlandia 4-Szwecja } 5 \text {-UE-12 }
$$


Rysunek 6. Współczynniki zmienności eksportu, importu, konsumpcji, inwestycji, badań i rozwoju oraz długu publicznego (\% PKB) w UGiW, Danii, Finlandii, Szwecji i UE-12 w latach 1998-2013

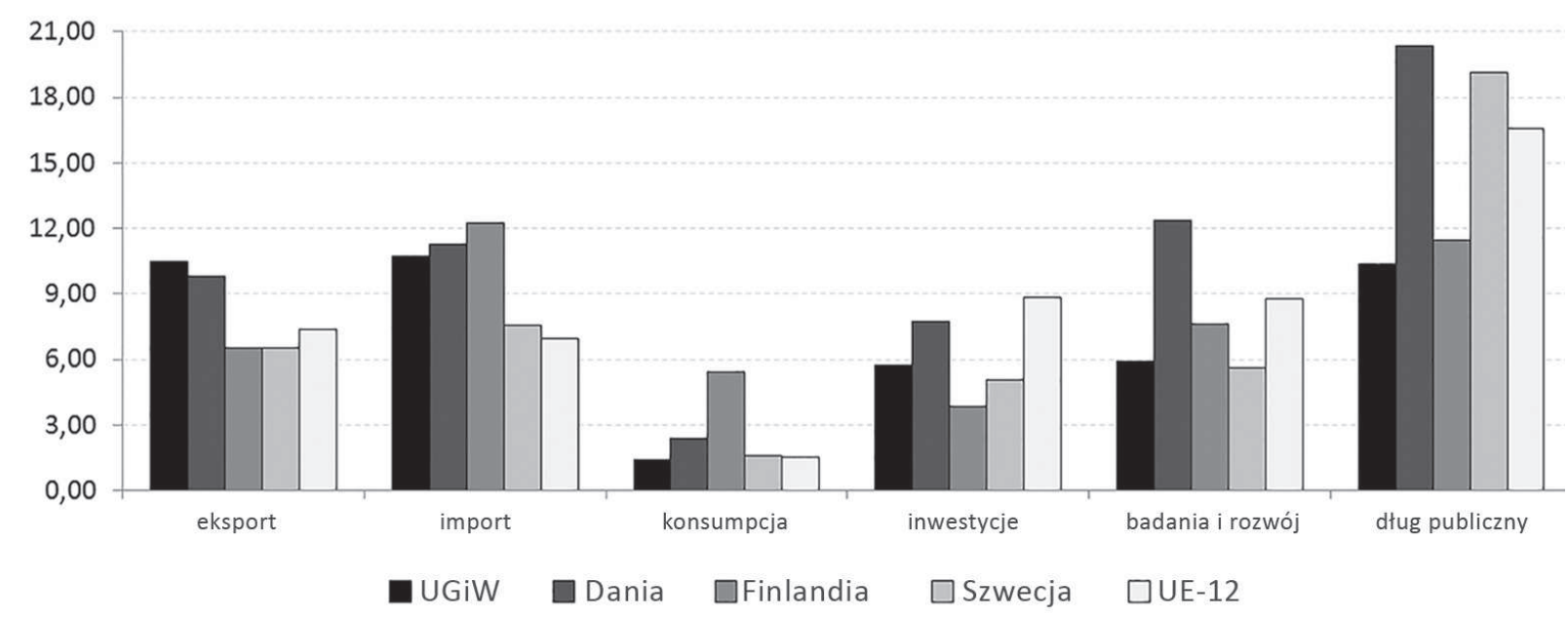

Źródło: Opracowanie własne na podstawie danych statystycznych Eurostatu.

\subsection{Implikacje globalnego kryzysu dla perspektywy integracji z UGiW}

Gospodarki Danii, Finlandii i Szwecji są silnie powiązane politycznie i gospodarczo z pozostałymi krajami Unii Europejskiej, Unii Gospodarczej i Walutowej oraz Rady Nordyckiej. Starania integracyjne krajów skandynawskich mają na celu umiejętne połączenie przynależności do Unii Europejskiej z założeniami współpracy nordyckiej. Efektywność takiej koordynacji warunkuje gwarancję wewnętrznego i zewnętrznego bezpieczeństwa regionu Skandynawii. Wychodząc naprzeciw zmianom w Europie, pogłębianie integracji powinno stanowić podstawę partnerstwa europejsko-nordyckiego. Mimo to wraz ze wzrostem europejskiej integracji zainteresowanie Skandynawów współpracą nordycką ulega zmniejszeniu ${ }^{56}$.

Perspektywa integracji z UGiW zależna jest od przyszłego spełnienia kryteriów konwergencji. W przypadku krajów skandynawskich związana jest ona $\mathrm{z}$ jakością prowadzonej polityki pieniężnej i fiskalnej oraz determinacją polityczną i społeczną. Światowy kryzys gospodarczy, zapoczątkowany w 2007 r., potwierdził, że w fazie kryzysu i depresji cyklu koniunkturalnego zwiększa się ryzyko niespełnienia fiskalnych kryteriów konwergencji nominalnej ${ }^{57}$. Kryzys uwypuklił niejednorodność i problemy strukturalne państw tworzących strefę euro, występujące wewnętrzne i zewnętrzne

56 A.A. Weber, Challenges for Monetary Policy in the European Monetary Union, „Federal Reserve Bank of St. Louis Review" July/August 2011, No. 93(4), s. 235-242.

$57 \mathrm{~W}$ fazie ożywienia oraz rozkwitu zwiększeniu ulegają poziom produkcji, zatrudnienia, inwestycji i popytu. W konsekwencji rośnie ryzyko niespełnienia inflacyjnego kryterium konwergencji nominalnej. 
nierównowagi, pokazał, że przynależność do strefy euro nie zabezpiecza przed zawirowaniami w gospodarce światowe ${ }^{58}$. W następstwie kryzysu pojawiła się próba rezygnacji z unifikacji i integracji na rzecz zabezpieczenia interesów narodowych ${ }^{59}$.

W Szwecji i Danii najważniejszą przeszkodą w przystąpieniu do strefy euro jest negatywne nastawienie opinii publicznej do integracji walutowej. W Danii, ze względu na klauzulę opt-out, przyznaną na mocy Traktatu o Unii Europejskiej, konieczne będzie przeprowadzenie referendum w sprawie przyjęcia euro. Szwecja jest zobligowana do przyjęcia wspólnej waluty na mocy traktatu akcesyjnego z $1994 \mathrm{r}$. w najbliższym możliwym terminie. W krajach tych zarówno zwolennicy przyjęcia euro, jak i przeciwnicy integracji walutowej mają wiele mocnych argumentów. Za przystąpieniem do obszaru wspólnej waluty przemawia m.in. rezygnacja z kosztów transakcyjnych. Przeciwnicy wprowadzenia euro twierdzą natomiast, że możliwość prowadzenia niezależnej polityki pieniężnej pozwala na stworzenie atrakcyjniejszych niż w UGiW warunków dla inwestycji zagranicznych. W długim okresie pozostanie Danii i Szwecji poza strefą euro może wiązać się ze zbyt dużymi kosztami. Przyjęcie wspólnej waluty międzynarodowej powinno być głównym argumentem przystąpienia do UGiW. Obecnie korona duńska i szwedzka nie mają większego znaczenia $\mathrm{w}$ gospodarce światowej ${ }^{60}$.

Szwecja i Dania nadal będą się przyglądać, jak funkcjonuje UGiW oraz jak kształtuje się polityka monetarna EBC i polityka fiskalna poszczególnych krajów członkowskich. Należy podkreślić, że w następstwie globalnego kryzysu gospodarczego kraje te nie były w stanie wypełnić kryteriów konwergencji. Plany integracji walutowej Danii i Szwecji będą wymagać rewizji i odłożenia w czasie.

58 Finlandia, z jednym z najwyższych ratingów w strefie euro, silnie odczuwa skutki globalnego kryzysu finansowego. Winą za sytuację w gospodarce obarczany jest rząd fiński, który wprowadził politykę oszczędnościową. Doprowadziła ona do spadku popytu i nie wpłynęła na zmniejszenie rządowego zadłużenia. Sytuacja w Finlandii zwiększa wątpliwości dotyczące korzyści z przystąpienia do Unii Gospodarczej i Walutowej. Kraj jest jednym z ośmiu państw strefy euro, który w latach 2012 i 2013 odnotował spadek PKB. W związku z kryzysem fiński rząd oświadczył, że kraj woli wyjść ze strefy euro, niż spłacać długi krajów członkowskich. Należy podkreślić, że ewentualne opuszczenie przez Finlandię UGiW mogłoby znacznie pogłębić kryzys strefy euro.

59 A. Wojtyna, Polityka pieniężna w strefie euro: dawne obawy, nowe wyzwania, „Gospodarka Narodowa” listopad-grudzień 2008, nr 7(11-12), R. XIX s. 1-20; Polityka makroekonomiczna w warunkach kryzysu i jej wptyw na gospodarkę, red. Z. Dach, Wolters Kluwer Polska, Warszawa 2011; T. Kowalski, The Economic and Monetary Union countries vs. the global crisis, „Poznan University of Economics Review” 2012, Vol. 12, No. 2, s. 19-48.

${ }^{60}$ J. Milleville, Perspektywy rozszerzenia Europejskiej Unii Gospodarczej i Walutowej - korzyści i zagrożenia, „Zeszyty Naukowe” nr 109: Procesy integracji we współczesnej gospodarce światowej, Wydawnictwo AE w Poznaniu, Poznń 2008, s. 9-31; G.B. Wolff, The Euro Area Crisis: Policy Options Ahead, Resolving the European Debt Crisis, Special Report 21 Peterson Institute for International Economics, March 2012, s. 235-252; D. Wilsher, Law and the Financial Crisis: Searching for Europe's New Gold Standard, „European Law Journal" March 2014, Vol. 20, No. 2, s. 241-283. 
Pomimo sprzeczności interesów na arenie międzynarodowej integracja gospodarcza w Europie będzie postępować. Wspólna wieloletnia tradycja oraz zbieżne interesy krajów skandynawskich pozwolą na kontynuację współpracy gospodarczej zarówno w wymiarze jakościowym (wzrost konwergencji nominalnej i realnej), jak i geograficznym ${ }^{61}$. Przyszła integracja europejsko-nordycka będzie istotna z punktu widzenia utrzymania więzi z krajami pozostającymi poza Unią.

Głównym celem współpracy w Europie jest pogłębianie integracji gospodarczej poprzez zastępowanie indywidualnych działań - wspólnotowymi. Integracja europejska na przestrzeni wieków wpłynęła na obecny poziom rozwoju społeczno-gospodarczego krajów członkowskich. Nie wydaje się zatem realistyczny pogląd, że Dania, Finlandia i Szwecja będą w stanie prowadzić odmienną politykę gospodarczą. Kraje te mają swój interes w osiągnięciu stabilnego wzrostu, a kierunek działań powinien być taki sam lub podobny jak w innych krajach UE i UGiW.

\section{Zakończenie}

Przeprowadzona ocena integracji Danii, Finlandii i Szwecji z Unią Europejską i Unią Gospodarczą i Walutową wykazała zróżnicowaną reakcję tych krajów na współczesny kryzys finansowy.

W kontekście spowolnienia gospodarczego istotny okazał się stopień integracji krajów skandynawskich ze strefą euro, tj. przystąpienia Finlandii do Unii Gospodarczej i Walutowej, przyjęcia przez Danię klauzuli opt-out oraz objęcia Szwecji derogacją. Mierząc współpracę tych krajów z UE i UGiW, uwzględniono stan i charakter tego procesu w przypadku każdego państwa z osobna. Pogłębianie integracji

61 Relacje pomiędzy Islandią a Unią Europejską opierają się na islandzkim członkostwie w Europejskim Obszarze Gospodarczym. Pozwala to Islandii na dostęp do wspólnego rynku Unii Europejskiej. Globalny kryzys finansowy wpłynął na pogląd przewagi korzyści nad kosztami przyłączenia do UE. 17 lipca 2009 r. ambasador Islandii w Szwecji (podczas prezydencji Rady Unii Europejskiej) przekazał wniosek parlamentu Islandii o przystąpienie do Unii. Ze względu na kłopoty korony islandzkiej rząd zaproponował możliwość przyjęcia euro, bez przystępowania do UE. Komisja Europejska podtrzymała stanowisko, że Islandia nie może przystąpić do Unii Gospodarczej i Walutowej bez stania się pełnoprawnym członkiem UE. W czerwcu 2013 r. nowy rząd wycofał się z ubiegania o członkostwo Islandii w Unii Europejskiej. Islandia posiada status kandydata, lecz nie jest znana data zakończenia negocjacji oraz data przystąpienia do UE.

Pomiędzy Norwegią a Unią Europejską istnieje ścisła więź gospodarcza. Norwegia należy do Europejskiego Obszaru Gospodarczego. Trzykrotnie składała wniosek o członkostwo oraz posiadała status kandydata do UE. Negatywny stosunek do członkostwa w UE potwierdzają obawy poddania wspólnotowej kontroli bogactw naturalnych kraju (ryb, ropy naftowej i gazu ziemnego). Norwegia zostałaby płatnikiem unijnego budżetu ze względu na wysoki poziom PKB. Obecnie około 3/4 obywateli Norwegii jest przeciwko członkostwu w Unii Europejskiej. 
następowało w odmienny sposób. Najbardziej zróżnicowana była współpraca z unią monetarną. Najwyższy stopnień integracji z UE i UGiW osiągnęła Finlandia. Dania charakteryzowała się znacznym stopniem współpracy. W przypadku Szwecji poziom integracji był najniższy. Z punktu widzenia przeprowadzonej analizy interesy Danii, Szwecji i Finlandii w UE były zbieżne. Różnice w zaawansowaniu integracji krajów skandynawskich z UE i UGiW nie wykluczały współpracy między tymi państwami.

Zawirowania na globalnych rynkach finansowych oraz recesja gospodarcza osłabiły zdolność do spełnienia kryteriów konwergencji realnej i nominalnej. Problem ten dotknął wszystkie gospodarki rozwinięte UE. W mniejszym stopniu ujawnił się w Danii i Szwecji. W przypadku Finlandii kryzys na światowych rynkach finansowych potwierdził, że strefa euro nie chroni przed destabilizacją. Wpłynęło to na decyzję Danii i Szwecji odłożenia w czasie przystąpienia do wspólnego obszaru walutowego.

\section{Economic integration of Denmark, Finland and Sweden with the European Union}

This paper explores economic integration of the Scandinavian states (Denmark, Finland and Sweden) with the European Union during the global crisis. The aim of this paper is to present comparative study of different choices made by these countries with regard to the European integration: EMU opt - out clause in Denmark, membership of Finland in the European Monetary Union and derogation for Sweden - and as result different reaction to the financial and economic crises.

Keywords: financial crisis, Scandinavian countries, economic integration, European Union, Economic and Monetary Union

\section{L'Intégration économique du Danemark, de la Finlande et de la Suède au sein de l'Union européenne}

Ce document décrit l'intégration économique des pays scandinaves (Danemark, Finlande et Suède) dans l'Union européenne en temps de crise. L'article présente une étude comparative des différentes décisions prises par ces pays concernant l'intégration européenne - la clause d'opt-out de l'UEM au Danemark, la présence de la Finlande dans la zone euro et la dérogation accordée à la Suède - et, en conséquence, les réactions différentes face aux crises économiques et financières. 
Mots-clés: la crise financière, les pays scandinaves, l'intégration économique, l'Union européenne, l'Union économique et monétaire

\section{Экономическая интеграция Дании, Финляндии и Швеции в Европейский союз}

Статья исследует экономическую интеграцию стран Скандинавии (Дании, Финляндии и Швеции) в Европейский Союз во время глобального кризиса. Целью данной работы является сравнительный анализ, избранных в этих странах, разных путей интеграции в Европейский союз - получение так называемой оговорки о «не участии» (по англ. opt-out clause) в Дании, членство Финляндии в Европейском валютном союзе и отступление для Швеции - и реакций на финансовый и экономический кризисы.

Ключевые слова: финансовый кризис, скандинавские страны, экономическая интеграция, Европейский союз, Экономический и валютный союз 